\title{
INSIDENSI PENYAKIT DIARE BERDASARKAN KEPADATAN BAKTERI COLIFORM DI SUNGAI JAWI, KOTA PONTIANAK
}

Liza Syafitri $^{1)}$ Rahmawati $^{2)}$ Laili Fitria $^{1)}$

${ }^{1)}$ Program Studi Teknik Lingkungan,Jurusan Teknik Sipil, Fakultas Teknik, Universitas Tanjungpura Pontianak

${ }^{2)}$ Fakultas Matematika dan Ilmu Pengetahuan Alam (MIPA), Universitas Tanjungpura Pontianak Email : lizairtifays@gmail.com

\begin{abstract}
ABSTRAK
Sungai Jawi menjadi saluran primer yang digunakan oleh masyarakat setempat dan muara saluran sekunder dari kawasan perumahan. Bakteri coliform biasa dijadikan indikator keberadaan bakteri patogen yang dapat menyebabkan penyakit water borne disease yaitu diare. Hal tersebut menjadi dasar tujuan penelitian ini untuk mengetahui kepadatan bakteri coliform di saluran Sungai Jawi dan hubungannya terhadap parameter suhu, $\mathrm{pH}$, DO dan BOD serta insidensi penyakit diare di Sungai Jawi. Titik pengambilan sampel dilakukan di hulu, tengah dan hilir Sungai Jawi saat kondisi pasang-surut Sungai Kapuas pada bulan September 2016 jam 09.40 WIB (saat surut) dan jam 15.40 (saat pasang). Analisis hubungan kepadatan bakteri coliformterhadapparameter suhu, $\mathrm{pH}$, DO dan BOD serta insidensi diare menggunakan uji korelasi Pearson Product Momentsementara analisis hubungan masyarakat yang menggunakan air Sungai Jawi terhadap insidensi diare menggunakan uji Chi-Square. Hasil analisis kualitas air menunjukkan bahwa kepadatan bakteri coliform meningkat dari titik hulu menuju titik hilir dengan nilai 1501.500 MPN/100 ml saat pasang dan 930-11.000 MPN/100 ml saat surut. Analisis uji korelasi Pearson Product Moment menunjukkan adanya hubungan positif (berbanding lurus) parameter $\mathrm{pH}$ dan BOD serta hubungan negatif (berbanding terbalik) parameter suhu dan DO terhadap kepadatan bakteri coliform. Hasil uji korelasi juga menunjukkan adanya hubungan antara kepadatan bakteri coliform terhadap insidensi diare, dengan nilai koefisien korelasi -0,649 (pasang) dan $-0,695$ (saat surut). Sementara hasil analisis uji Chi-Square $(\mathrm{df}=1 ; \alpha=5 \%)$ menunjukkan adanya hubungan antara masyarakat pengguna air Sungai Jawi dan insidensi diare. Jadi, dapat disimpulkan air Sungai Jawi berpotensi sebagai faktor terjadinya diare di Sungai Jawi.
\end{abstract}

Kata Kunci :Diare, Coliform, Sungai Jawi, Pontianak

\begin{abstract}
Jawi River become the primary channel was used for local communites and estuary secondary channels from domestic areas. Coliform bacteria commonly used as indicators the presence of pathogenic bacteria that cause water borne disease suchdiarrhea. It's became the purpose of this study, to determine the density of coliform bacteria in Jawi River and its relationship of temperature, $p H, D O$ and BOD parameters and also incidence of diarrhea in Jawi River. The sampling point in the upstream, midstream and downstream Jawi River which observed current tidal Kapuas River on September 2016 at 09.40 am (low tide) and 15.40 pm (high tide). Analysis relationship density of coliform bacteria between temperature, $\mathrm{pH}, \mathrm{DO}$ and $B O D$ parametersand also incidence of diarrhea used Pearson Product Moment Correlation test, in while analysis of communitieswas using Jawi River with the incidence of diarrhea used Chi-Square test. The results of water quality showed that density of coliform bacteria increase from upstream to downstream which value 150-1.500 MPN/100 ml at high tide and 930-11.000 MPN/100 ml at low tide. Analysis of Pearson Product Moment Correlation testshowed $\mathrm{pH}$ and BOD parameters hadpositive relationship (linier), temperature and DO parameters had negative relationship (inverse) with density of coliform bacteria. Result of correlation test showed relationship between density of coliform bacteria and incidence of diarrhea, with correlation coefficient is -0,649 (high tide) and $0,695$ (low tide). In while, analyses of Chi-Square test ( $d f=1 ; \alpha=5 \%)$ showed relationship between communities was using Jawi River water and incidence of diarrhea. Thus, we can conclude that Jawi River water had potential as incidence factor of diarrhea in Jawi River.
\end{abstract}

Keywords : Diarrhea, Coliform, Jawi River, Pontianak 


\section{* Pendahuluan}

Sungai Jawi di Kota Pontianak merupakan saluran primer yang terletak diantara Kecamatan Pontianak Barat dan Kecamatan Pontianak Kota serta menjadi muara bagi saluran sekunder yang berasal dari kawasan pemukiman sekitar. Hasil penelitian Khotimah (2009) menunjukkan bahwa kepadatan bakteri coliform tertinggi ditemukan di muara Sungai Jawi dengan nilai $8.425 \mathrm{MPN} / 100 \mathrm{ml}$ saat surut dan $160.825 \mathrm{MPN} / 100 \mathrm{ml}$ saat pasang. Penggunaan air sungai yang tercemar dapat mempengaruhi derajat kesehatan masyarakat pengguna dengan timbulnya penyakit bawaan air (water borne disease) salah satunya adalah diare. Oleh sebab itu, perlu dilakukan penelitian untuk mengetahui kepadatan bakteri coliform serta menganalisis kaitannya dengan insidensi diare di sepanjang wilayah saluran Sungai Jawi. Tujuan dari penelitian ini yaitu untuk mengetahui nilai kepadatan bakteri coliform di Sungai Jawi, mengetahui hubungan parameter suhu, $\mathrm{pH}, \mathrm{DO}$ dan BOD terhadap kepadatan bakteri coliform serta hubungan antara kepadatan bakteri coliform dan insidensi penyakit diare di Sungai Jawi.

\section{* METOdOLOGI PENELITIAN}

Penelitian ini dilaksanakan di Sungai Jawi, Kota Pontianak seperti yang ditampilkan pada Gambar 1. Waktu penelitian dilaksanakan dari bulan September 2016 hingga bulan November 2016. Analisis sampel DO dan BOD dilakukan di Laboratorium Kualitas dan Kesehatan Lahan, Fakultas Pertanian serta analisis coliform dan E.coli dilakukan di Laboratorium Mikrobiologi, Fakultas Teknik.

Alat yang digunakan untuk penelitian ini yaitu rambu ukur, bola kasti yang telah diberi pemberat, meteran, tali rapia, lakban hitam,botol sampel $250 \mathrm{ml}$, botol winkler $300 \mathrm{ml}$, jerigen $1 \mathrm{~L}$,thermometer, $\mathrm{pH}$ meter, gelas erlenmeyer, tabung reaksi, mikropipet, pipet tetes, hot plate, incubator, Laminar Air Flow, autoklaf, tabung durham, neraca analitik dan spatula.Bahan yang digunakan yaitu akuades, karbol, alkohol $70 \%$, media LB (Lactose Broth), media BGLB (Brilliant Green Lactose Broth) dan EMB (Eosin Metyhlene Blue) Agar.

Pengambilan sampel dilaksanakan pada tanggal 16 September 2016 saat pasang-surut Sungai Kapuas, yakni pada jam 09.40 WIB (fase surut) dan jam 15.40 WIB (fase pasang) di titik hulu (Parit Haruna), tengah (JI. Suwignyo) dan hilir (Gertak I Sungai Jawi). Pengambilan sampel DO dan BOD diambil menggunakan botol ukuran $1 \mathrm{~L}$ dan botol winkler300 $\mathrm{ml}$ yang dilakukan secara duplo, sementara sampel mikrobiologi menggunakan botol sampel ukuran $250 \mathrm{ml}$ yang sudah disterilkan dengan autoklaf dan diambil di tiga titik (tepi kiri dan kanan serta tengah saluran).

Volume sampel pengenceran yang digunakan untuk uji MPN yaitu $1 \mathrm{ml}, 0,1 \mathrm{ml}$ dan 0,01 ml menggunakan seri 3 tabung reaksi (WHO, 1996). Uji coliform mengacu pada SNI 01-2332.1-2006, yaitu meliputi uji pendugaan, uji penegasan dan uji pelengkap. Rumus yang digunakan untuk mencari nilai kepadatan coliform yaitu (APHA, 2005):

$$
\begin{aligned}
& \text { MPN } / 100 \mathrm{ml}=\text { nilai tabel MPN } / 100 \mathrm{ml} \times \frac{\text { kolom pertama periakuan (ml) }}{\text { pengenceran tabung palingkecil (mil }} \\
& M P N / 100 \mathrm{ml}=\text { nilai tabel } M P N / 100 \mathrm{ml} \times \frac{1 \mathrm{ml}}{0,1 \mathrm{ml}}
\end{aligned}
$$

(Persamaan 1)

Data primer yang didapat meliputi data kualitas airserta hasil kuisioner. Data sekunder yang digunakan yaitu data pasang-surut Sungai Kapuas, data insidensi diare dari puskesmas Pal V, Pal III dan Kom Yos Sudarsoserta data jumlah penduduk Kelurahan Pal V, Sungai Jawi, Sungai Jawi Dalam dan Mariana. Penentuan jumlah sampel responden menggunakan rumus cross-sectionalyang ditampilkan di Persamaan 2 (Pebriadi, 2013). 


$$
n=\frac{z_{1-\alpha / 2}^{2} \times p(1-p) N}{d^{2}(N-1)+Z_{1-\alpha / 2}^{2} \times p(1-p)}
$$

$$
\begin{aligned}
& \text { dimana: } \mathrm{n} \quad=\text { ukuran sampel } \\
& Z_{1-\alpha / 2}^{2}=\text { indeks kepercayaan }(1,96) \\
& \mathrm{N}=\text { jumlah populasi Kelurahan Pal V, Sungai Jawi Dalam, Sungai Jawi dan } \\
& \text { Mariana } \\
& \mathrm{p} \quad \text { proporsi penggunaan air sungai sebagai bahan baku air }(1,59 \%) \text { oleh } \\
& \quad \text { masyarakat Kota Pontianak } \\
& \mathrm{d} \quad=\text { proporsi toleransi estimasi yang dikehendaki (5\%) }
\end{aligned}
$$

Analisis hubungan parameter suhu, pH, DO dan BOD terhadap kepadatan bakteri coliform menggunakan uji korelasi sehingga didapat nilai korelasi dan arah hubungan antar parameter yang dianalisis. Sementara analisis hubungan insidensi diare dan kepadatan bakteri coliform menggunakan uji korelasiPearson Product Moment. Apabila nilai $\mathrm{R}$ hitung mendekati 1 atau -1 , maka antar variabel tersebut memiliki hubungan, tetapi jika nilai $R$ hitung adalah 0 , maka tidak ada hubungan antar variabel yang diuji. Uji korelasi Pearson Product Moment menggunakan rumus sebagai berikut: (Sugiyono, 2016):

$r=\frac{\sum x y}{\sqrt{\sum x^{2} \times \sum y^{2}}}$, dengan $\alpha=5 \%$

(Persamaan 3)

Jadi, hipotesis yang digunakan untuk uji korelasi Pearson Product Moment yaitu:

- $\mathrm{H}_{0}: \mathrm{R}=0$

- $H_{a}: R \neq 0$

Analisis hubungan masyarakat yang menggunakan air Sungai Jawi dan insidensi diare yang terjadi menggunakan uji Chi-Square $\left(\mathrm{X}^{2}\right)$ yang mengacu pada penelitian Pebriadi (2013) dengan hipotesis yang digunakan yaitu:

- $\mathrm{H}_{0} \quad$ = tidak ada hubungan antara insidensi diare dan kepadatan coliform

- $\mathrm{H}_{\mathrm{a}} \quad$ = ada hubungan antara insidensi diare dan kepadatan coliform

Setelah menentukan hipotesis, analisis hubungan insidensi diare dan kepadatan coliform dilihat dari nilai $X^{2}$ hitung dan $X^{2}$ tabel dengan ketentuan sebagai berikut:

- Jika $X^{2}$ hitung $\geq X^{2}$ tabel, maka $H_{0}$ ditolak

- Jika $X^{2}$ hitung $\leq X^{2}$ tabel, maka $H_{a}$ diterima

Prinsip dasari uji Chi-Squareyaitu membandingkan frekuensi yang terjadi (observasi) dengan frekuensi harapan (eskpektasi). Uji Chi-Squaremenggunakan rumus sebagai berikut (Soebagyo, 2005):

$$
\begin{aligned}
& x^{2}=\sum \frac{(O-E)^{2}}{C}, \text { dengan } \mathrm{df}=(\mathrm{b}-1)(\mathrm{k}-1) \\
& E=\frac{\text { marginal baris } \times \text { marginal kolom }}{N}
\end{aligned}
$$




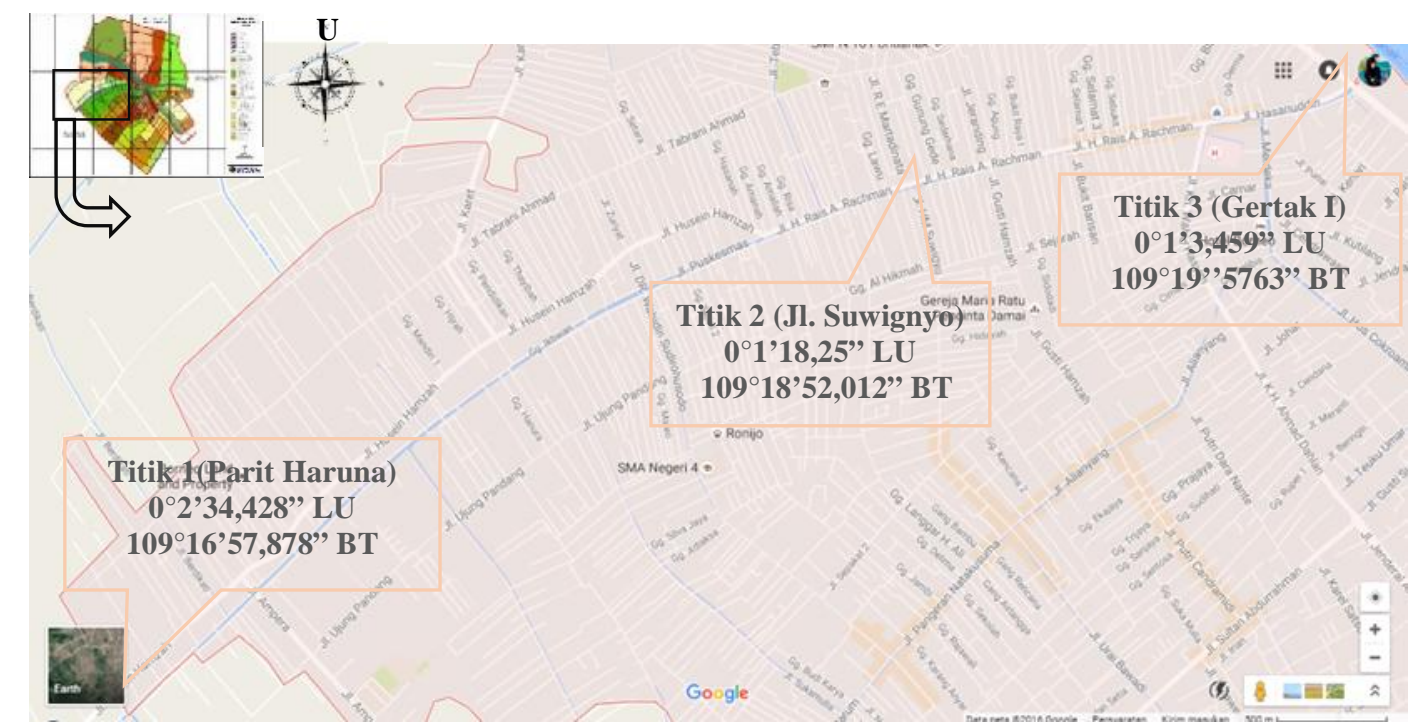

Gambar 1. Titik pengambilan sampel di Sungai Jawi, Kota Pontianak

\section{HASIL DAN PEMBAHASAN}

\section{Analisis Kualitas Air Sungai Jawi}

Nilai suhu saat surut lebih rendah dibandingkan saat pasang, hal ini dikarenakan perbedaan waktu pengambilan sampel yang mempengaruhi suhu lingkungan saat sampling (Saputri, 2014). Selain itu perbedaan suhu di setiap titik juga dipengaruhi perbedaan cuaca, kelembaban udara dan intensitas pemaparan cahaya matahari (Romanto, 2013). Suhu air Sungai Jawi berkisar antara $28-31^{\circ} \mathrm{C}$ dan termasuk baku mutu kelas I, II, III. Berutu (2001) mengatakan jika suhu perairan berkisar $27-29^{\circ} \mathrm{C}$ bahkan $30-31^{\circ} \mathrm{C}$ masih dalam tahap suhu normal untuk perairan tropis.

Tabel 1. Hasil Analisis Kualitas Air Sungai Jawi

\begin{tabular}{|c|c|c|c|c|c|c|c|c|c|c|c|}
\hline \multirow{3}{*}{ No. } & \multirow{3}{*}{ Lokasi } & \multicolumn{10}{|c|}{ Hasil Pengukuran } \\
\hline & & \multicolumn{5}{|c|}{ Pasang } & \multicolumn{5}{|c|}{ Surut } \\
\hline & & $\begin{array}{l}\text { Suhu } \\
\left({ }^{\circ} \mathrm{C}\right)\end{array}$ & pH & $\begin{array}{c}\mathrm{DO} \\
(\mathrm{mg} / \mathrm{L})\end{array}$ & $\begin{array}{l}\text { BOD } \\
\text { (mg/L) }\end{array}$ & $\begin{array}{c}\text { Coliform } \\
\text { (MPN/100 ml) }\end{array}$ & $\begin{array}{l}\text { Suhu } \\
\left({ }^{\circ} \mathrm{C}\right)\end{array}$ & $\mathrm{pH}$ & $\begin{array}{c}\mathrm{DO} \\
(\mathrm{mg} / \mathrm{L})\end{array}$ & $\begin{array}{l}\text { BOD } \\
\text { (mg/L) }\end{array}$ & $\begin{array}{c}\text { Coliform } \\
\text { (MPN/100 ml) }\end{array}$ \\
\hline 1. & $\begin{array}{l}\text { Parit Haruna } \\
\text { (hulu) }\end{array}$ & 28 & 7 & 5,67 & 15,17 & 150 & 30 & 6,8 & 6,78 & 13,64 & 930 \\
\hline 2. & $\begin{array}{l}\text { Jl. Suwignyo } \\
\text { (tengah) }\end{array}$ & 29 & 7,8 & 5,51 & 13,05 & 430 & 31 & 6,9 & 7,96 & 9,49 & 2.400 \\
\hline 3. & $\begin{array}{l}\text { Gertak I } \\
\text { Sungai Jawi } \\
\text { (hilir) }\end{array}$ & 28 & 8 & 1,14 & 27,96 & 1.500 & 28 & 8 & 3,98 & 16,52 & 11.000 \\
\hline \multicolumn{2}{|c|}{ Nilai Rata-Rata } & 28,3 & 7,5 & 4,1 & 18,72 & 693,3 & 29,6 & 8 & 6,24 & 13,21 & $4.776,7$ \\
\hline
\end{tabular}


pH air Sungai Jawi berada pada rentang 6,8 - 8 dan termasuk baku mutu kelas I, II dan III. Pada titik hulu dan tengah, nilai pH lebih rendah dibanding titik hilir karena daerah hulu masih ada beberapa masyarakat yang menggunakan air Sungai Jawi untuk keperluan mencuci baju, peralatan makan bahkan mandi sehingga air buangan dari aktivitas tersebut langsung masuk ke aliran air. Menurut Romanto (2013), sisa dari aktivitas tersebut diduga membawa bahan organik yang akan didekomposisi oleh mikroorganisme air. Nilai pH juga dipengaruhi buangan limbah yang mengubah konsentrasi hidrogen dalam air menjadi asam ataupun basa akibat kandungan zat kimia yang terkandung di dalamnya (Wardhana, 2001).

Tabel 2. Baku Mutu Kelas Air Sungai Jawi

\begin{tabular}{|c|c|c|c|c|c|c|c|c|c|c|c|}
\hline \multirow{3}{*}{ No. } & \multirow{3}{*}{ Lokasi } & \multicolumn{8}{|c|}{ Baku Mutu Kelas Air Peraturan Pemerintah No. 82 Tahun 2001} & \multicolumn{2}{|c|}{$\begin{array}{c}\text { SK. Dirjen PPM dan } \\
\text { PLPno. 1/PO.03.04.PA.91 }\end{array}$} \\
\hline & & \multicolumn{4}{|c|}{ Pasang } & \multicolumn{4}{|c|}{ Surut } & Pasang & Surut \\
\hline & & Suhu & pH & DO & BOD & Suhu & pH & DO & BOD & \multicolumn{2}{|c|}{ Coliform } \\
\hline 1. & $\begin{array}{l}\text { Parit Haruna } \\
\text { (hulu) }\end{array}$ & I - III & I- III & II & IV & I- III & $I-I I I$ & I & IV & C & C \\
\hline 2. & $\begin{array}{l}\text { Jl. Suwignyo } \\
\text { (tengah) }\end{array}$ & I - III & $I-I I I$ & II & IV & I- III & $\mathrm{I}-\mathrm{III}$ & I & III & C & D \\
\hline 3. & $\begin{array}{l}\text { Gertak I } \\
\text { Sungai Jawi } \\
\text { (hilir) }\end{array}$ & I - III & I - III & III & IV & I - III & I - III & III & IV & D & $\mathrm{E}$ \\
\hline
\end{tabular}

Nilai DO air Sungai Jawi bervariasi ditiap titik dan mempengaruhi baku mutu kelas air seperti yang ditampilkan pada Tabel 1 dan Tabel 2. Kandungan oksigen terlarut bergantung pada suhu, kehadiran tanaman untuk proses fotosintesis, tingkat penetrasi cahaya yang bergantung pada kedalaman dan kekeruhan air, tingkat kederasan aliran air dan jumlah bahan organik yang diuraikan dalam air (Sastrawidjaya dalam Putra, 2013). Aliran air Sungai Jawi mendapat limpasan air buangan dari komplek perumahan, pasar dan ruko. Umumnya konsentrasi DO disuatu perairan bersifat sementara atau musiman dan berfluktuasi (Putra, 2013).

Nilai BOD air Sungai Jawi bervariasi ditiap titik dan mempengaruhi baku mutu kelas air seperti yang ditampilkan pada Tabel 1 dan Tabel 2. Penurunan nilai BOD dalam air disebabkan oleh berkurangnya kandungan oksigen di badan perairan karena buangan limbah berpengaruh terhadap lingkungan sungai serta karakteristik limbah yang masuk tanpa adanya pengolahan langsung dibuang ke badan sungai (Fardiaz dalam Saputri, 2014). Perbedaan nilai BOD disetiap titik juga diakibatkan masuknya zat pencemar yang diterima oleh badan air dari daerah sekitarnya seperti daerah pemukiman, pertokoan dan lahan terbuka (Trofisa, 2011).

Nilai kepadatan bakteri coliform air Sungai Jawi bervariasi ditiap titik dan mempengaruhi baku mutu kelas air seperti yang ditampilkan pada Tabel 1 dan Tabel 2. Setelah dilakukan uji pelengkap menggunakan media EMB, air Sungai Jawi positif mengandung bakteri E.coli di setiap titik sampling saat pasang dan surut. Bakteri coliform masuk ke perairan melalui aliran sungai serta limpasan air hujan sehingga kelimpahan bakteri semakin tinggi (Kuswandi dalam Feliatra, 2002). Saat surut kepadatan bakteri coliform lebih tinggi dibandingkan saat pasang. Hal ini dikarenakan saat pasang terjadi pengenceran akibat masuknya aliran air dari Sungai Kapuas sehingga debit air bertambah. Sementara saat surut, debit air tetap namun buangan limbah terus bertambah, sehingga bakteri coliform yang masuk ke Sungai Jawi semakin tinggi (Khotimah, 2009). 
Beberapa masyarakat yang tinggal berdekatan dengan Sungai Jawi masih menggunakan air tersebut untuk keperluan mandi dan mencuci baik digunakan secara langsung ataupun disedot menggunakan pompa menuju ke rumah penduduk. Adanya kegiatan tersebut juga mempengaruhi kualitas air Sungai Jawi dan berpotensi menimbulkan dampak terhadap kesehatan masyarakat.

Hubungan Parameter suhu, pH, DO dan BOD Terhadap KepadatanColiform
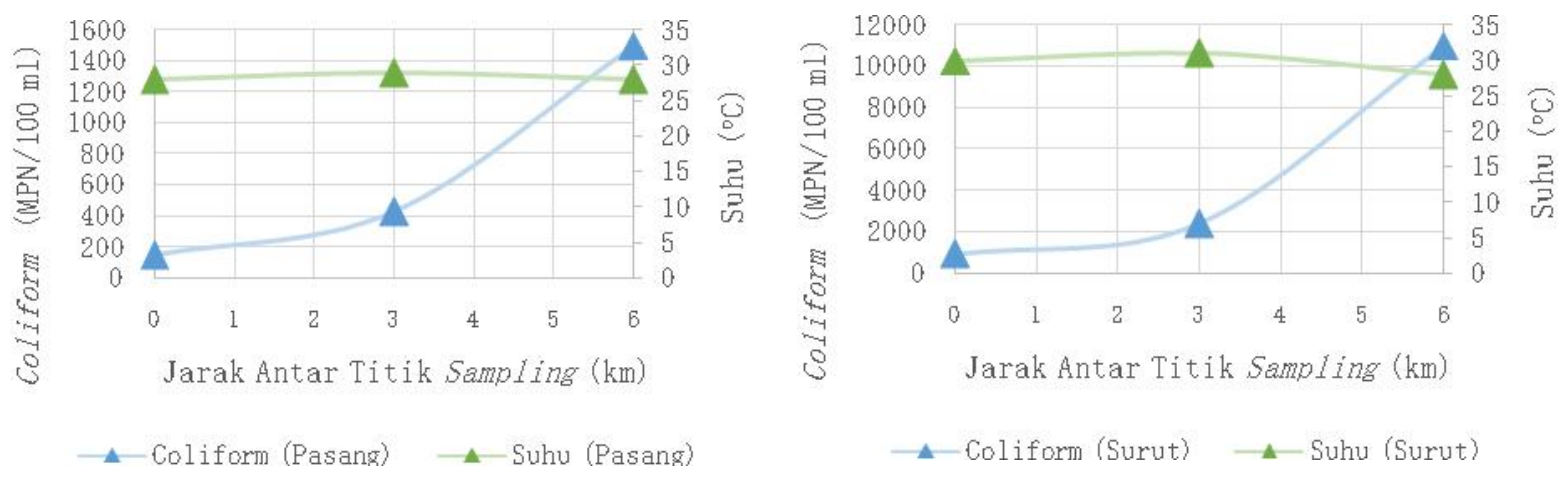

Gambar 2. Hubungan parameter coliform dan suhu saat pasang dan surut
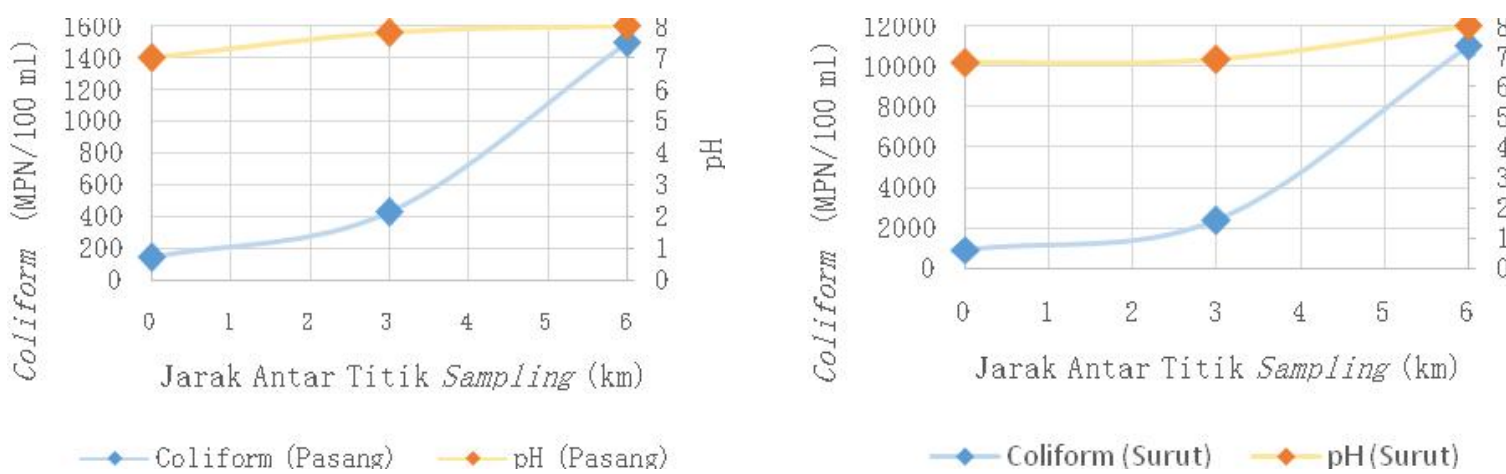

Gambar 3. Hubungan parameter coliform dan $\mathrm{pH}$ saat pasang dan surut
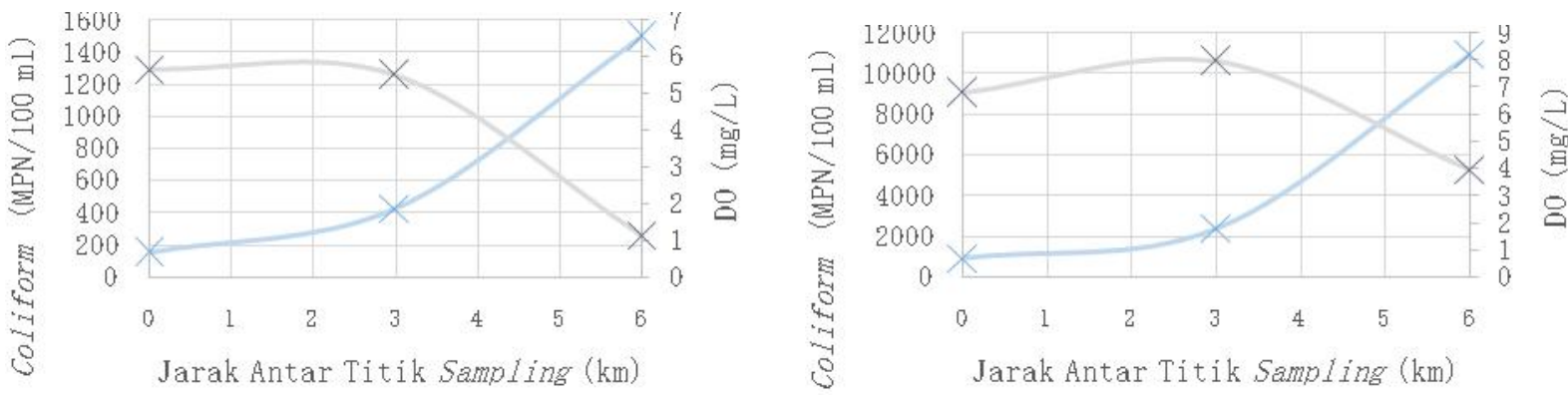

$x$ Coliform (Pasang) $\quad x-$ DO (Pasang)

Gambar 4. Hubungan parameter coliform dan DO saat pasang dan surut 

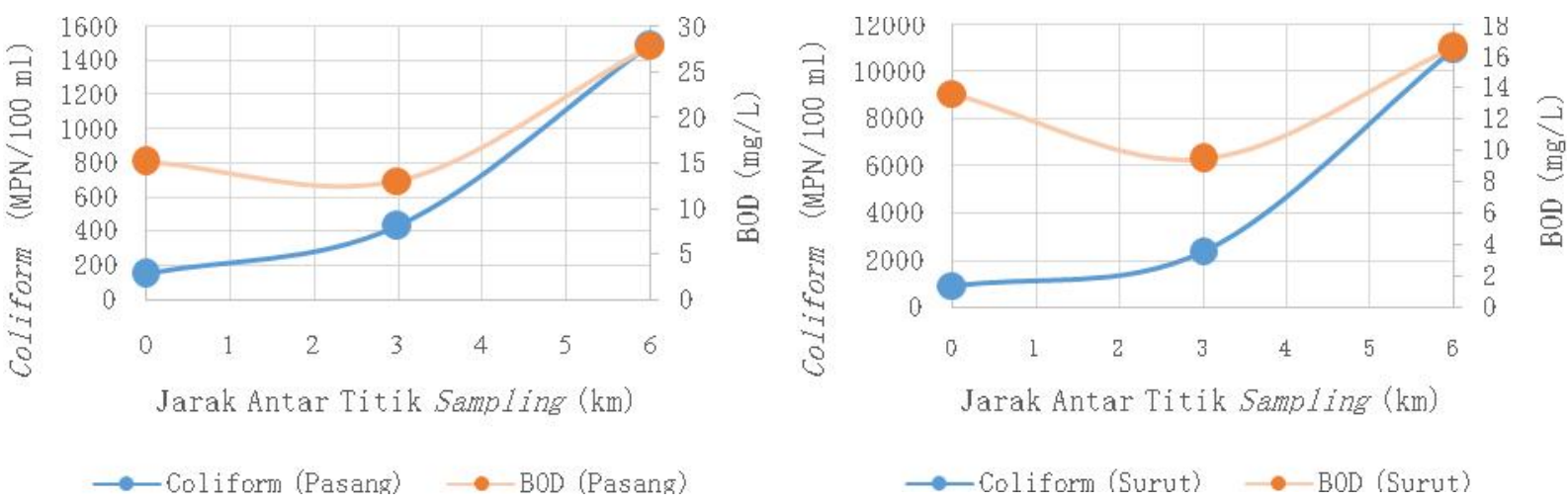

Gambar 5. Hubungan parameter coliform dan BOD saat pasang dan surut

Parameter suhu dan DO saling memiliki hubungan terhadap parameter coliform dengan arah hubungan berbanding terbalik seperti yang ditampilkan pada Gambar 2 dan Gambar 4 saling berbanding terbalik. Hal ini juga terjadi pada nilai korelasi yang dihasilkan yaitu $-0,32$ saat pasang dan $-0,892$ saat surut untuk parameter suhu serta $-0,986$ saat pasang dan $-0,91$ saat surut untuk parameter DO.

Parameter $\mathrm{pH}$ dan BOD saling memiliki hubungan terhadap parameter coliform dengan arah hubungan berbanding lurus, seperti yang ditampilkan pada Gambar 3 dan Gambar 5 berbanding lurus. Hal ini juga terjadi pada nilai korelasi yang dihasilkan yaitu 0,7904 saat pasang dan 0,9982 saat surut untuk parameter $\mathrm{pH}$ dan 0,9462 saat pasang dan 0,7227 saat surut untuk parameter BOD.

\section{Hubungan Kepadatan BakteriColiform Terhadap Insidensi Penyakit Diare}

Berdasarkan rumus persamaan 2, didapat 96 responden meliputi Kelurahan Pal V, Sungai Jawi, Sungai Jawi Dalam dan Mariana. Masyarakat yang mengalami penyakit diare biasa berobat di puskesmas terdekat dan tempat dokter praktik. Sementara hasil analisis jawaban responden berdasarkan jenis pertanyaan tertutup dengan pilihan jawaban ya/tidak ditampilkan pada Tabel 4.

Tabel 3. Analisis Data Kuisioner Penelitian

\begin{tabular}{clcccc}
\hline \multirow{2}{*}{ No. } & \multicolumn{2}{c}{ Jenis Pertanyaan } & \multicolumn{2}{c}{ Jawaban } & \multicolumn{2}{c}{$\%$} \\
\cline { 3 - 6 } & & Ya & Tidak & Ya & Tidak \\
\hline 1. & Pernah mengalami diare & 40 & 56 & 42 & 58 \\
\hline 2. & Menggunakan air Sungai Jawi & 61 & 35 & 64 & 36 \\
\hline 3. & Sampah dibuang ke Sungai Jawi & 20 & 76 & 21 & 79 \\
\hline 4. & Limbah dibuang ke Sungai Jawi & 64 & 32 & 67 & 33 \\
\hline 5. & Ada septik tank & 0 & 96 & 0 & 100 \\
\hline
\end{tabular}

Hasil analisis menggunakan uji korelasi Pearson Product Moment(R hitung), menunjukkan nilai korelasi saat pasang dan surut mendekati -1 atau $R \neq 0$, sehingga adahubungan antara kepadatan bakteri coliformdan insidensi diare di Sungai Jawi. Berdasarkan persamaan 3, didapat nilai korelasi saat pasang yaitu $-0,649$ dan saat surut yaitu $-0,695$. Koefisien determinasi $R$ hitung saat pasang yaitu 0,421 dan 0,489 saat surut yang berarti varians pada variabel insidensi diare $42,1 \%$ saat pasang dan $48,9 \%$ saat surut dapat dijelaskan melalui varians yang terjadi pada kepadatan 
bakteri coliform, sementara 57,9\%.Persamaan regresi dari hasil analisis nilai korelasi

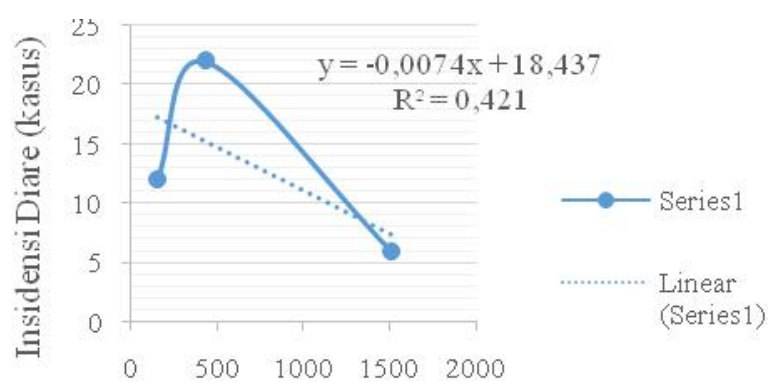

Kepadatan Bakteri Coliform Saat Pasang $(\mathrm{MPN} / 100 \mathrm{ml})$

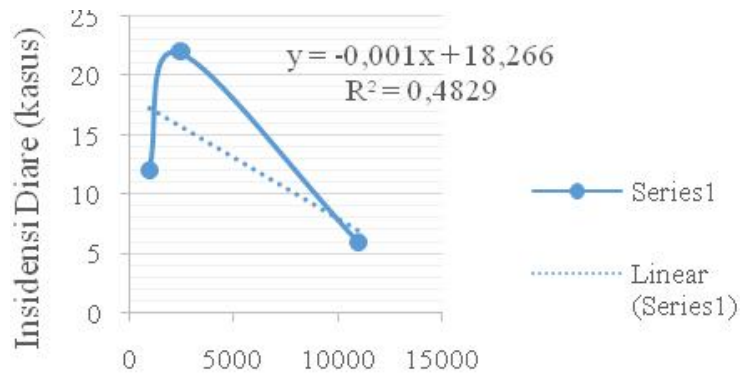

Kepadatan Bakteri Coliform Saat Surut $(\mathrm{MPN} / 100 \mathrm{ml})$

kepadatan bakteri coliform dan insidensi diare ditunjukkan pada Gambar 6

Gambar 6. Persamaan regresi insidensi diare dan nilai kepadatan bakteri coliform saatpasang dan surut

Berdasarkan persamaan 3 dan persamaan 4, maka dapat membuktikanhipotesis yang di uji, dengan nilai $\alpha$ yaitu $5 \%$ dan nilai df yaitu 1 , yang ditampilkan dalam Tabel $\mathbf{4}$ sebagai berikut.

Tabel 4. Nilai Observed dan Expected Insidensi Diare dan Kepadatan Coliform

\begin{tabular}{|c|c|c|c|c|c|}
\hline \multirow[t]{2}{*}{ Pengguna air Sungai Jawi } & \multicolumn{2}{|c|}{$\begin{array}{c}\text { Penderita Diare } \\
\text { (Observed) }\end{array}$} & \multirow[t]{2}{*}{ Total } & \multicolumn{2}{|c|}{$\begin{array}{c}\text { Penderita Diare } \\
\text { (Expected) }\end{array}$} \\
\hline & $\mathrm{Ya}$ & Tidak & & $\mathrm{Ya}$ & Tidak \\
\hline $\mathrm{Ya}$ & 30 & 31 & 61 & 25,42 & 35,58 \\
\hline Tidak & 10 & 25 & 35 & 14,58 & 20,42 \\
\hline Total & 40 & 56 & 96 & 40 & 56 \\
\hline
\end{tabular}

Nilai $X^{2}$ hitung $(3,88)$ lebih besar dibanding nilai $X^{2}$ tabel $(3,841)$ sehingga $H_{0}$ ditolak. Jadi, dapat disimpulkan bahwa adanya hubungan antara insidensi diare yang terjadi pada masyarakat sekitar Sungai Jawi dan masyarakat yang menggunakan air Sungai Jawi. Faktor yang mempengaruhi terjadinya insidensi diare di Sungai Jawi selain adanya kualitas bakteriologis air juga dipengaruhi oleh aktivitas masyarakat sekitar yang masih menggunakan air tersebut untuk keperluan sehari-hari seperti kegiatan mencuci peralatan makan. Peralatan makan yang dibilas menggunakan air yang terkontaminasi bakteri, menyebabkan peralatan tersebut terindikasi adanya bakteri yang melekat dan mengakibatkan masuknya bakteri ke dalam tubuh melalui jalur oral. Menurut Pebriadi (2013), penggunan air Sungai Kapuas yang positif mengandung E.coli memiliki hubungan dengan kejadian diare yang dialami masyarakat Kelurahan Siantan Hilir. Hal ini sesuai pula dengan hasil penelitian Amaliah (2010) yang mengatakan bahwa perilaku dalam menggunakan sumber air bersih dan penggunaan jamban dapat berpengaruh terhadap kejadian diare.Insidensi diare juga terjadi pada masyarakat yang tidak menggunakan air Sungai Jawi. 


\section{KESIMPULAN}

Berdasarkan hasil dan analisis pembahasan yang telah dilakukan maka dapat disimpulkan bahwa:

1. Nilai kepadatan bakteri coliform di Sungai Jawi saat pasang dan surut terus mengalami kenaikan dari titik hulu hingga titik hilir yakni mulai dari 150-1.500 MPN/100 ml saat pasang dan 930-11.000 MPN/100 ml saat surut.

2. Parameter $\mathrm{pH}$ dan $\mathrm{BOD}$ memiliki hubungan positif (berbanding lurus) dan parameter suhu serta DO memiliki hubungan negatif (berbanding terbalik) terhadap nilai kepadatan bakteri coliform.

3. Hasil analisis menggunakan uji korelasi Pearson Product Moment menunjukkan adanya hubungan antara kepadatan bakteri coliform dan insidensi diare terhadap masyarakat yang tinggal di pinggir Sungai Jawi.

\section{UCAPAN TERIMA KASIH}

Penulis mengucapkan terima kasih kepada masyarakat Sungai Jawi yang telah bersedia menjadi responden dalam penelitian ini, khususnya masyarakat di Kelurahan Sungai Jawi, Sungai Jawi Dalam, Pal V dan Mariana.

\section{DAFTAR PUSTAKA}

Amaliah, S. 2010. Hubungan Sanitasi Lingkungan dan Faktor Budaya dengan Kejadian Diare pada Anak Balita di Desa Toriyo Kecamatan Bandosari Kabupaten Sukoharjo. Fakultas Kedokteran. Universitas Muhammadiyah Semarang.

APHA. 2005. Standard Methodes for The Examination of Water and Wastewater. $20^{\text {th }} \mathrm{Ed}$. American Public Health Assotiation, American Water Works Association Water Environment Federation.

Berutu, P. 2001 Kajian Parameter Fisika, Kimia dan Biologi dalam Kaitannya dengan Kebersihan Ikan di Kawasan Perairan Danau Toba di Sumatra Utara.

Khotimah, S. 2009. Kepadatan Bakteri Coliform di Sungai Kapuas Kota Pontianak. Prosiding Semirata FMIPA Universitas Lampung.

Pebriadi, D. 2013. Hubungan Antara Penggunaan Air Sungai dan Kejadian Diare pada Keluarga yang Bermukim di Sekitar Sungai Kapuas Kelurahan Siantan Hilir Pontianak. Naskah Publikasi Fakultas Kedokteran Universitas Tanjungpura.

Putra, R. 2013. Kajian Beban Pencemaran dan Kualitas Air Sungai Arau di Kota Padang, Fakultas Perikanan dan Sumber Daya Air. Institut Pertanian Bogor.

Romanto, 2013. StatusKualitas Air Sungai Ciambulawung, Banten. Institut Pertanian Bogor.

Saputri, A. 2014. Analisis Sebaran Oksigen Terlarut Pada Sungai Raya. Skripsi Teknik Lingkungan. Universitas Tanjungpura.

Soebagyo, S. 2005.Dasar-Dasar Statistika. Yoyakarta: Fakultas Kedokteran Hewan. Universitas Gadjah Mada.

Sugiyono. 2016. Statistika untuk Penelitian. Bandung: Penerbit Alfabeta.

Trofisa, D. 2011. Kajian Beban Pencemaran dan Daya Tampung Pencemaran Sungai Ciliwung di Segmen Kota Bogor. Institut Pertanian Bogor.

Wardhana, W.A. 20014. Dampak Pencemaran Lingkungan. Yogyakarta: Penerbit Andi. 
World Health Organization. 1996. Water Quality Monitoring - A Practical Guide to the Design and Implementation of Freshwater Quality Studies and Monitoring Programmes. Edited by Jamie Bartram and Rizhard Balance. Geneva. 